\title{
Introduction
}

The Adenauer Era-Anxieties and Traumas of Violence in the Postwar Period ${ }^{1}$

\section{Jost Dülffer}

History, Universität zu Köln

Researching and writing contemporary history move forward in a certain rhythm. Today, the 1960s are the decade of major interest, whereas the 1970s increasingly are becoming the testing ground of new approaches and reinterpretations. By contrast, the 1950s seem of little interest-with most of the issues solved and most sources accessible. But this could be a false impression, especially if one takes into account the dominant views on this period that have become popular in the last years. After 1989/90, with the fall of the Berlin Wall, the unification of Germany, and the end of the Cold War, many historians developed and corroborated an interpretation of the postwar decades-a now widely accepted master narrative of the "German question." With the benefit of hindsight, they claimed that Konrad Adenauer's policy of Western integration was a necessary and inevitable course, which facilitated eventual reunification. Other political options would have rendered the Federal Republic of Germany (FRG) dangerously open to stronger communist pressure or even would have presented the Soviet Union with the opportunity to expand its empire to Germany as a whole.

This master narrative entails further hypotheses, depending on either a conservative or a more liberal point of view. On the one hand, conservative historians assume that Adenauer correctly had predicted and anticipated the end of Soviet rule in Eastern Europe and the collapse of the German Democratic Republic (GDR)-which simply occurred later than the first West German chancellor had expected. On the other hand, liberals assert that the Ostpolitik of Willy Brandt and others after the late 1960s paved the way for West 
German conciliation and a policy of normalization towards the East, while Adenauer earlier had achieved firm integration in the West with the former enemies of World War II by means of political freedom and economic prosperity. Thus, these historians perceive the Christian Democratic Union's (CDU) policy towards the West, as well as reconciliation with the East, as supplementary, but necessary steps to facilitate the outcome of $1989 / 90$. In this sense, they are two sides of the same coin. The titles of recent books indicate the dominance of such success stories, although differing substantially in many aspects: Heinrich-August Winkler's The Long Way to the West, Konrad Jarausch's Recivilizing Germans or Edgar Wolfrum's The Successful Democracy. ${ }^{2}$ Nevertheless, there are good reasons to undertake a critical reassessment of the 1950s from different perspectives, paying particular attention to sources and methodologies.

Emotions and their impact on culture play an important role especially in political history. For example, it is a truism that terrorism has created new qualities of violence after $9 / 11$ and subsequently has induced new anxieties, which have permeated many societies to a larger or lesser degree. Similarly, the years of the early Cold War, especially the first phase of massive East-West confrontation, also were characterized by latent and manifest violence in and between societies worldwide and by corresponding fears. These anxieties were especially pronounced with regard to Europe and West Germany during the years that are now commonly known as the "Adenauer era," when the old politician from Rhöndorf was the first chancellor of the newly founded Federal Republic of Germany from 1949-1963. It is this important foundational period to which this special issue of German Politics and Society is dedicated.

Several additional observations are necessary to capture the dynamics and context of this historical epoch. When the FRG and GDR were founded in 1949, World War II had ended just four years previously, and only after the 1960s could one speak properly about its "long shadow," rather than its direct impact. With the exception of a few neutral states, most of Europe had suffered directly from war, violence, and destruction. All countries, including the victors like Great Britain, had mobilized their economies and were virtually bankrupt afterwards. Germany had plundered the parts of Europe it occupied in order to contribute as much as possible for its total war. 
Battle itself had caused immense destruction in production capacities, transportation infrastructure, and housing. From this backdrop, the Marshall Plan and the European Recovery Program necessarily envisaged a long period of reconstruction for Western Europe-policies that were supported widely in Western Europe. Immediate human suffering was even more pressing. Death estimates pass fifty million, most killed in the Eastern European theater. The country that suffered most in absolute figures was the Soviet Union-in relative numbers Poland and Yugoslavia. Above all, the genocide of European Jews and the mass murder of many groups defined as enemies by Nazi Germany cannot be assessed in terms of contemporary national boundaries, and remain the central events in this lethal war. The loss of life, as well as the millions more who were disabled and wounded, only hints at the unprecedented human misery that caused postwar trauma. Horror had become normal during the war and this kind of desensitization had a fundamental impact during reconstruction. We now have good data regarding the material reconstruction after the war, but the mental dispositions of the populace and their slow modification in the following decades are not yet analyzed sufficiently. Suffice it to say, that the mental and material aftermath of the European war permeated explicitly or subconsciously the overall political culture of the ensuing decades. ${ }^{3}$

After the polarization into two blocs became an indubitable fact in Europe, a second fear arose: the mutual concern about ideological and violent subversion by the other camp, and the weakness each side felt to defend itself against the latent or manifest threat of the other. Of course, the specific content was very different. While open societies in the West feared economic crises, social tensions and impoverishment as the seedbed for communist subversion, party leaders in the Soviet sphere feared an open flow of information as a destabilizing factor. Moreover, the concept of the expansionist "capitalist" world also contributed to an image of the enemy that aggressively endangered the construction of socialism in the East. While overt social misery was overcome in the West already in the early 1950s, Eastern European attempts to catch up economically with the West, especially after Nikita Khrushchev took over the leadership of the Soviet Union in years after1953, never materializedbut anxieties persisted. 
Military threat perceptions aggravated these anxieties. They were especially pronounced in the West, where military planners compared the strength of the Red Army and the evolving armies of the satellite states with relative Western weakness after the immediate postwar demobilization. On the other hand, Soviet propaganda connected an allegedly economically "aggressive" capitalism with military adventurism and "roll-back" policies aimed at driving the Soviet Union out of Central and Eastern Europe. Both sides feared the prospect of domestic unrest spurred by foreign military intervention. Finally, one of the most important military concerns, in the light of World War II, was German rearmament. This holds true for the former enemies as well as for the (West) Germans themselves, ${ }^{4}$ albeit for different reasons.

Nuclear armaments added another horror scenario to these perceptions. The questions of political pressure, blackmail, and the threat of annihilation loomed over the doctrine of deterrence. The U.S. could make political use of the atomic bomb after 1945, but the Soviet Union followed soon with its own atomic capability in 1949. Moreover, Soviet acquisition of the hydrogen bomb in 1953 only one year after the United States blasted the first device, was the prerequisite for a political instrumentalization of nuclear weapons. While the United States retained superiority in aircraft as carriers for nuclear bombs for a long time, the Soviet Union developed a capability for delivery of long-range missiles after the successful launch of the Sputnik satellite in 1957. Only around 1962 did both sides gain the potential to destroy each other.. The assumption of "mutually assured destruction" that stabilized the arms race created psychological horror scenarios. The stockpiling of nuclear devices and delivery systems continued at an accelerated tempo with high economic costs. Bernard Brodie, Henry Kissinger, Helmut Schmidt, Franz Joseph Strauß, and George F. Kennan, to name but a few, discussed scenarios of nuclear annihilation in public. Military planners were confronted with unanswerable dilemmas of how to wage a future nuclear war, while having to cope with its outcome. The public also had to face the dimensions of thermonuclear war, which was especially threatening for Germany, since it would become the most probable battlefield in the case of hostilities. ${ }^{5}$ All these points created 
a climate of cultural fear that with historical hindsight begins to be difficult to analyze and is challenging to grasp today. ${ }^{6}$

Finally, in light of these multiple anxieties, the "German question," well known as it was, figured prominently as an additional factor. It formed a European problem since the 19th century, but in this form was a consequence of World War II, the boundless German war of conquest and annihilation. Headaches plagued all the major allied powers already in their wartime planning. How could one create a new European order and necessarily integrate the Germans and Germany? Even after the great powers gave up "dismemberment" officially as a preferred solution to the German question, the foundation of two separate states in 1949 still left the question of their unification open. The structural changes the great powers had agreed upon verbally at Potsdam indicated the direction for the process of German reintegration into Europe. But, the fundamentally divergent occupation regimes and the ensuing social changes in the different parts of Germany soon rendered it a point of reference mostly on the Soviet side. "Back to Potsdam" at least in Western interpretations became an analogy for the Sovietization of the West. How far this development was necessary, is part of a still ongoing historical debate. The German problem in itself thus was central for the European international order, but it acquired a new charging by the remilitarization in both states. This development took place under the control of the Western powers and the Soviet Union, to be sure. But in the light of World War II, Europeans and the new Cold War opponents neither could nor would regard the remilitarization of the German states as the normal attempt of two newly founded states to protect themselves against aggression: German remilitarization was a major part of increasing tensions between East and West. The same is true with respect to the outfitting of the Bundeswehr with nuclear carriers since the late 1950s. Of course, the alleged revival of German militarism in the FRG was a convenient catchword for Soviet and GDR propaganda, but it may have been more, if one takes into account the recent experiences of many countries with German occupation, mainly in the East of the continent. 


\section{Notes}

1. This special issue is based on an international conference organized by the BMW Center for German and European Studies, Georgetown University in cooperation with the German Historical Institute, Washington, D.C. in March 2006. Orienting questions included: Which part and role did the Big Four play for the division of Germany? How did they deal with rebuilding Germany and integrating their zones into the two Cold War camps? What implications and priorities were placed on possibilities of (re) unification and Western or Eastern integration? Only a selection of the many excellent contributions to this conference can be assembled here.

2. Heinrich-August Winkler, Der lange Weg nach Westen (Munich, 2000/2001); Konrad Jarausch, Die Umkehr (Stuttgart, 2005). The English translation, After Hitler: Recivilizing Germans, (Oxford, 2006), has an even more outspoken teleological tendency; Edgar Wolfrum, Die geglückte Demokratie: Geschichte der Bundesrepublik Deutschland von ihren Anfängen bis zur Gegenwart (Stuttgart, 2006).- My special thanks go to Sönke Kunkel for invaluable help in the editing process in Germany.

3. Fundamental is the collective volume: Klaus Naumann, ed., Nachkrieg in Deutschland (Hamburg, 2001).

4. Michael Geyer, "Der Kalte Krieg, die Deutschen und die Angst: Die westdeutsche Opposition gegen Wiederbewaffnung und Kernwaffen," in Naumann, (see note 3), 267-318. The English version is in: Hanna Schissler ed., The Miracle Years: A Cultural History of West Germany, 1949-1968 (Princeton, 2001), 376-408; See also Michael Geyer, "America in Germany: Power and the Pursuit of Americanization," in The German-American Encounter. Conflict and Comparisons between Two Cultures, 1800-2000, eds., Frank Trommler and Elliot Shove (New York, 2001), 121-144 .

5. See Bruno Thoß, NATO-Strategie und nationaler Verteidigungsbeitrag: Planungen und Aufbau der Bundeswehr unter den Bedingungen der massiven Vergeltungsstrategie, 19521960 (Munich, 2005).

6. Marc Trachtenberg, A Constructed Peace: The Making of the European Settlement, 1945-1963 (Princeton, 1999); Werner Link, Der Ost-West-Konflikt: Die Organisation der internationalen Beziehungen im 20. Jahrhundert (Stuttgart, 1980). 